Revista Destaques Acadêmicos, Lajeado, v. 10, n. 4, 2018. ISSN 2176-3070

DOI: http://dx.doi.org/10.22410/issn.2176-3070.v10i4a2018.2036

http://www.univates.br/revistas

\title{
AVALIAÇÃO DA UTILIZAÇÃO DE ÁGUA OZONIZADA NO PROCESSO DE DESINFECÇÃO DE UM SISTEMA DE ORDENHA
}

\author{
Bárbara Weber ${ }^{1}$, Alberto Valdameri², Cleide Borsoi ${ }^{3}$
}

Resumo: O leite é um produto essencial na dieta humana, além de ser a base para produção de outros alimentos. No Brasil, a pecuária leiteira possui um papel importante na economia, gerando empregos e insumos para outros ramos da indústria. A qualidade do produto fornecido ao consumidor é o principal aspecto da produção, e leva em consideração a saúde do animal, o processo de ordenha, as diferentes etapas da indústria e toda a cadeia de distribuição. O processo de ordenha é ponto mais crítico e onde o risco de contaminações é evidente, por isso é essencial uma boa higienização do animal e dos equipamentos utilizados no processo. Assim, o objetivo desse trabalho consiste em avaliar a utilização de água ozonizada no processo de desinfecção de um sistema de ordenha canalizada na produção leiteira, comparando com o processo químico convencional. Foram avaliados os parâmetros microbiológicos de Contagem Bacteriana Total (CBT) e Contagem de Células Somáticas (CCS) do leite obtido nos processos citados, a fim de comparar os métodos, bem como foi avaliada a composição do leite. Também foi realizado um comparativo da viabilidade econômica e ambiental dos processos de desinfecção utilizados. Comparando os resultados obtidos para CBT verificou-se uma diminuição dos valores obtidos ao aplicar o sistema de desinfecção com água ozonizada, com uma concentração de 0,049 ppm. O processo utilizando água ozonizada apresentou-se vantajoso economicamente e ambientalmente em comparação ao químico convencional. Com isso, a desinfecção com água ozonizada torna-se viável na substituição de procedimentos que utilizam produtos químicos e geram efluentes danosos ao ambiente.

Palavras-chave: Processo químico. Água ozonizada. Desinfecção. Ordenha canalizada.

1 Engenheira Química pela Universidade do Vale do Taquari - Univates, RS. E-mail: barbara. weber@universo.univates.br

2 Engenheiro Eletricista pela Pontifícia Universidade Católica do Rio Grande do Sul - PUC, RS. E-mail: alberto@alvap.com.br

3 Doutora em Engenharia de Materiais pela Universidade Federal do Rio Grande do Sul (UFRGS), RS. E-mail: cleide.borsoi@univates.br 


\section{INTRODUÇÃO}

A pecuária leiteira é um segmento essencial para a economia brasileira, gerando empregos e riquezas, além de consumir insumos para a produção, indústrias e cooperativas. Outro aspecto importante desse setor da economia é o fato de que essa atividade se mantém viável nas propriedades rurais dos pequenos agricultores. O leite é um produto essencial para dieta humana e, também, um insumo importante na produção de outros alimentos, como queijos, iogurtes, chocolates, creme de leite, entre outros (CÔNSOLI; NEVES, 2006).

Segundo o relatório da Companhia Nacional de Abastecimento (CONAB), no ano de 2016, o Brasil destacou-se como o quinto maior produtor mundial de leite, alcançando uma produção de 34,6 milhões de toneladas no ano. O estado do Rio Grande do Sul obteve uma produção de 951.174 mil litros de leite produzidos no terceiro trimestre de 2017, conforme pesquisa realizada pelo IBGE (IBGE, 2017).

A qualidade do produto que será entregue ao consumidor deve seguir as normas da Instrução Normativa (IN) nº 62, publicada em 2011 pelo Ministério da Agricultura, Pecuária e Abastecimento (MAPA), que define os parâmetros de qualidade do leite, indicados pela composição química, características físico-químicas e higiene. Níveis de CBT e CCS são características essenciais para a definição da qualidade, uma vez que se espera que o leite apresente baixas contagens bacterianas, ausência de microrganismos patogênicos ao ser humano, ausência de resíduos de medicamentos veterinários, e mínima contaminação com produtos químicos ou toxinas microbianas (BRASIL, 2011).

Problemas no manejo e na higiene da ordenha, sanidade da glândula mamária e refrigeração ineficiente podem gerar um produto de má qualidade, os quais podem ser evitados utilizando boas práticas de produção e fabricação. A avaliação microbiológica é um indicativo importante para a verificação das condições de produção e armazenamento do leite. O processo de ordenha possui alguns pontos críticos, entre eles pode-se citar o ambiente no qual ocorre a ordenha, bem como a saúde do animal, a higienização dos equipamentos e do próprio agricultor. A taxa e os tipos de microrganismos presentes no produto são influenciados pelo interior e pelo exterior do úbere e pelos equipamentos utilizados tanto no processo de ordenha como em laticínios. A microbiota do interior do úbere da vaca contém bactérias, mesmo que o animal seja saudável, que podem contaminar o leite no momento da ordenha. Naturalmente é uma carga pequena, porém quando o animal se encontra doente podem ser encontradas grandes quantidades do agente etiológico da doença. Devido a isso, é essencial manter o animal sempre saudável para realizar a ordenha (ORDÓÑEZ, 2005; ROSA et al., 2017).

$\mathrm{Na}$ produção leiteira canalizada a qualidade do produto final está diretamente ligada à higienização dos equipamentos de ordenha. Como 
o leite entra em contato direto com o conjunto de ordenhas, o copo coletor, a tubulação de leite e a unidade final, é importante que a limpeza ocorra no final de cada ordenha, garantindo que sejam removidos imediatamente os resíduos de leite e as sujeiras. A eficácia da desinfecção da ordenhadeira está relacionada a diversos fatores, entre eles pode-se citar a frequência de utilização do maquinário, o tempo de contato da higienização, o tipo de produto e sua concentração utilizada na limpeza. Devido a isso, torna-se fundamental a desinfecção do sistema de ordenha, seja por métodos físicos ou químicos (MENDONÇA; GUIMARÃES; BRITO, 2012; ROSA et al., 2017).

$\mathrm{Na}$ indústria de alimentos um dos principais produtos utilizados na desinfecção é o cloro, devido a sua capacidade de inativação de uma grande gama de células vegetativas. $\mathrm{O}$ baixo custo do produto torna-se um atrativo, porém alguns subprodutos do cloro são extremamente corrosivos quando entram em contato com superfícies metálicas. Além disso, podem causar problemas de saúde, como irritação na pele e danos nas mucosas, e serem potencialmente cancerígenos. A eficácia desses desinfetantes contra os microrganismos precisa ser relevante, pois é necessário um alto poder de destruição dos mesmos. No entanto, mesmo com alto poder de eficiência, esse modelo de processo gera resíduos químicos ao ambiente. Como opção alternativa de sanitização, pode ser utilizado o ozônio em meio aquoso (O'DONNELL et al., 2012; SHMIDELL, 2001).

As propriedades bactericidas do ozônio em solução aquosa permitem que o mesmo seja uma opção na substituição de parte dos produtos químicos na sanitização de equipamentos. A eficácia da utilização do ozônio no processo está ligada à temperatura, $\mathrm{pH}$ e quantidade de matéria orgânica presente no sistema. Um dos principais benefícios do ozônio é a utilização em sistema de lavagem e enxágue em uma série de ciclos da superfície interna de equipamentos, como tanques, tubulações, máquinas e homogeneizadores. A vantagem da recirculação com água fria é a reutilização dos produtos e da água, por um tempo determinado no processo, reduzindo custos (LANITA; SILVA, 2008; O'DONNELL et al., 2012; SILVA et al., 2011).

O ozônio é um potente agente antimicrobiano de alta capacidade de oxidação, inativando microrganismo através do rompimento do envoltório celular, dispersando os constituintes citoplasmáticos. Nas indústrias alimentícias a utilização da ozonização pode ser benéfica na higienização de superfícies, na sanitização de equipamentos, no reuso de águas residuais e na redução de demanda biológica de oxigênio (DBO) e demanda química de oxigênio (DQO).Quando aplicado em um meio aquoso possui propriedades bactericidas relevantes, podendo ser utilizado na desinfecção de equipamentos (GUZEL-SEYDIM; GREENE; SEYDIM, 2004;O'DONNELL et al., 2012; RESTAINO et al., 1995; RIBEIRO et al., 2017; ROBERTO et al., 2017).

No estudo realizado por Greene; Few; Serafini, (1993), o qual avaliou a eficiência da ozonização na desinfecção de superfícies de aço inoxidável 
utilizadas na indústria do leite, $99 \%$ das bactérias foram removidas. As bactérias vegetativas que foram eliminadas com a utilização de um sistema com água ozonizada são responsáveis pela deterioração microbiológica do leite, afetando a qualidade final do produto. Com isso, os resultados mostram que a ozonização é eficaz na destruição de bactérias presentes em superfícies de contato, mesmo com uma alta taxa de microrganismos e material orgânico. De acordo com o estudo realizado por Cavalcante et al., (2015), a higienização com água ozonizada foi eficiente na redução de microrganismos naturalmente presentes na alface e no crescimento dos mesmos. Foram acompanhados a contagem de coliformes totais, termotolerantes, bolores e leveduras, variando o tempo de imersão em 1, 2 e 3 minutos em água ozonizada a uma concentração de $1 \mathrm{ppm}$. Os resultados demonstraram que após três minutos de aplicação houve uma inativação total de coliformes totais e termotolerantes e uma redução significativa dos demais microrganismos.

Além da eficiência em um processo de desinfecção é preciso avaliar também a sustentabilidade do processo. A produção sustentável de alimentos tem se tornado um aspecto de extrema importância para os consumidores, que estão cada vez mais conscientes e exigindo produtos mais seguros e com menor impacto à saúde humana e ao meio ambiente. Para isso, torna-se fundamental que os agricultores produzam o leite utilizando de forma eficiente os recursos naturais, bem como reduzindo os impactos sobre o meio ambiente (FAO, 2013; BEIRÃO-DA-COSTA et al., 2014).

Diante disso, o objetivo deste trabalho consiste em avaliar a utilização de água ozonizada no processo de desinfecção de um sistema de ordenha canalizada na produção leiteira comparando com o processo químico convencional, avaliando a atividade microbiológica do leite utilizando os métodos CBT e CCS, a composição do leite obtido após a higienização e a avaliação da viabilidade econômica e ambiental desses processos.

\section{MATERIAL E MÉTODOS}

A pesquisa foi realizada em duas etapas. Na primeira etapa foi avaliada a utilização apenas do sistema convencional de higienização do sistema de ordenha. Após foi avaliada a substituição de uma etapa convencional pela utilização de água ozonizada. Os sistemas de desinfecção foram aplicados em uma propriedade rural com um processo de ordenha canalizada, com vacas do tipo Jersey, no Vale do Taquari, Rio Grande do Sul, sendo avaliado um período de um mês em cada uma das etapas. Na primeira etapa do trabalho, as amostras foram coletadas em dezembro de 2016. Para a segunda etapa, e comparação dos dados, coletou-se amostras em dezembro de 2017.

Durante a primeira etapa do trabalho aplicou-se o sistema convencional de desinfecção no processo de ordenha canalizada. As ordenhas foram realizadas em dois períodos do dia, na parte da manhã e à noite, denominadas 
de turno B e A, respectivamente. Após a primeira ordenha realizou-se um enxágue com $40 \mathrm{~L}$ de água para a remoção inicial dos resíduos e, em seguida foi aplicada a desinfecção do sistema utilizando 40 Lágua aquecida a $75^{\circ} \mathrm{C}$ com uma solução de detergente desengordurante alcalino clorado com $4 \%$ de cloro ativo. A concentração utilizada foi de $50 \mathrm{~mL}$ da solução para $10 \mathrm{~L}$ de água. A solução circulou pelo sistema de ordenhas por 15 minutos e, posteriormente, realizouse um enxágue com 40 L água fria proveniente da rede de abastecimento para a remoção completa da solução alcalina. Após a desinfecção aguardou-se um período de aproximadamente 12 horas para que seja realizada a ordenha do período da noite. Após a segunda ordenha o processo de desinfecção já descrito foi realizado novamente. A Figura 1(A) apresenta o fluxograma do processo de desinfecção convencional do sistema de ordenha canalizada avaliado.

Na segunda etapa do trabalho utilizou-se o sistema com água ozonizada como método alternativo para a desinfecção do processo de ordenha canalizada, em um dos ciclos de limpeza. Substitui-se apenas uma das etapas devido a presença de gordura nas tubulações e equipamentos, que precisam ser removidas com água quente e produtos químicos, uma vez que o ozônio não possui essa capacidade. A ordenha foi realizada no período da manhã, inicialmente realizou-se um enxágue com $40 \mathrm{~L}$ utilizando água ozonizada durante 15 minutos com uma concentração de 0,049 ppm. Assim como no processo convencional, a ordenha foi realizada no período da manhã e, após a primeira ordenha, realizou-se o enxágue com $40 \mathrm{~L}$ de água para a remoção inicial dos resíduos e, em seguida foi aplicada a desinfecção do sistema utilizando $40 \mathrm{~L}$ água aquecida a $75^{\circ} \mathrm{C}$ com uma solução de detergente desengordurante alcalino clorado com $4 \%$ de cloro ativo, para remover a gordura que possa ficar alojada no equipamento. A concentração utilizada foi de $50 \mathrm{~mL}$ da solução para $10 \mathrm{~L}$ de água. A solução circulou pelo sistema de ordenhas por 15 minutos e, posteriormente, foi realizado um enxágue com $40 \mathrm{~L}$ de água fria proveniente da rede de abastecimento, para a remoção completa da solução alcalina. No período da noite realizou-se um novo enxágue com $40 \mathrm{~L}$ utilizando água ozonizada com uma concentração de 0,049 ppm, a temperatura ambiente e após a ordenha dos animais. Após a ordenha, $40 \mathrm{~L}$ de água ozonizada com a mesma concentração circularam pelo sistema durante 15 minutos, não sendo necessário outro enxágue com água antes da próxima ordenha. É importante salientar que no processo utilizando água ozonizada os enxágues após a ordenha são realizados com a mesma água utilizada anteriormente, reaproveitando a mesma. A Figura 1 (B) apresenta o fluxograma do processo de desinfecção utilizando água ozonizada na substituição de uma etapa de desinfecção convencional. 
Figura 1 - Fluxograma do sistema químico convencional de desinfecção (A) e do sistema com ozonização na desinfecção (B) de um sistema de ordenha canalizada.

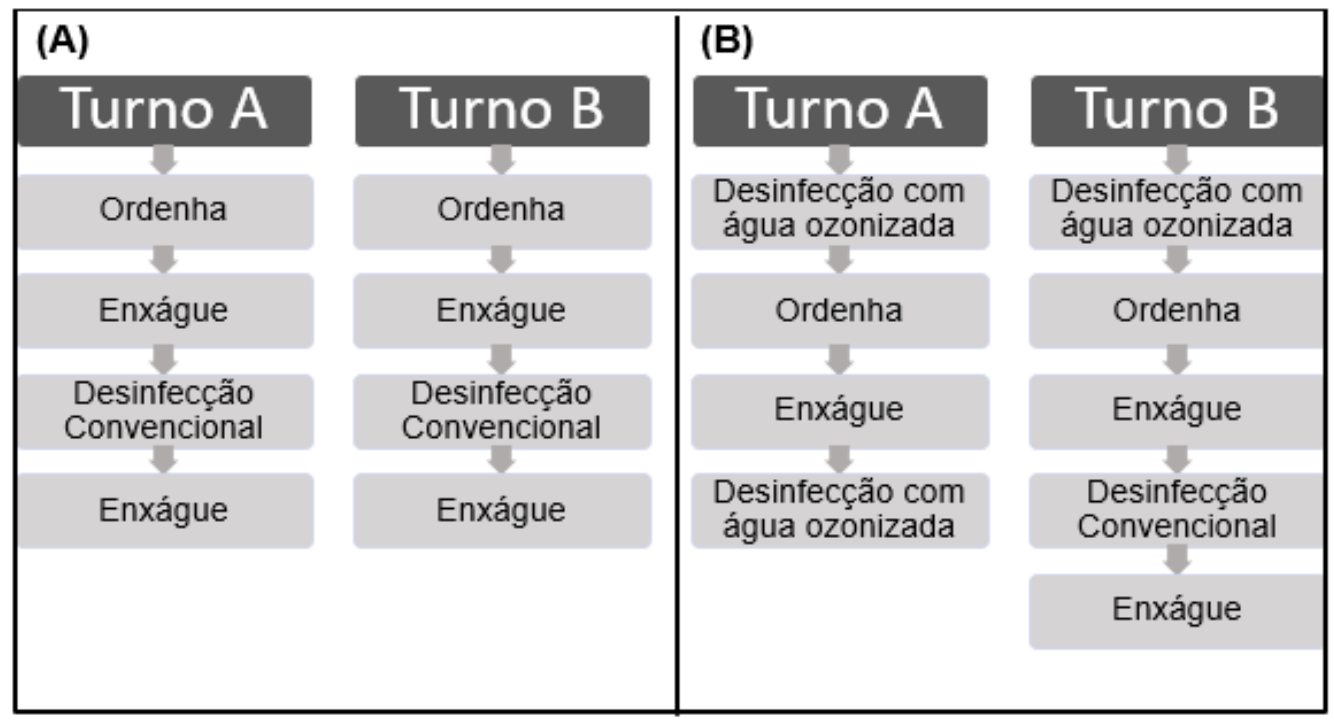

Fonte: Dos autores (2018).

Para a remoção de incrustações provenientes de sais presentes no leite e outras sujidades minerais e para que as mesmas não influenciassem nos resultados na pesquisa, aplicou-se duas vezes por semana uma solução de detergente ácido desincrustante. A aplicação foi feita utilizando $50 \mathrm{~mL}$ do ácido para $10 \mathrm{~L}$ de água e foi realizada nas duas etapas do estudo.

A água ozonizada foi obtida através de um gerador de ozônio desenvolvido pela empresa ALVAP Engenharia Ltda. O funcionamento do gerador está baseado no efeito corona, a uma tensão de alimentação de 220 $\mathrm{V}$ e uma potência de $40 \mathrm{~W}$. O gás ozônio gerado é incorporado na água e permanecerá na forma de bolhas, para que as mesmas possam atacar a superfície da ordenhadeira e os microrganismos presentes. O processo de ozonização da água foi realizado no momento da aplicação da mesma na desinfecção do sistema de ordenha.

Na primeira e na segunda etapa do trabalho as amostras de leite foram coletadas duas vezes ao dia, uma vez por semana, durante quatro semanas. A primeira coleta foi realizada no período da manhã e a outra no período da noite, ambas no momento da ordenha. As amostras foram coletadas em frascos esterilizados fornecidos pelo laboratório e armazenadas sob refrigeração para serem enviadas para análise.

As análises microbiológicas de CBT, CCS e composição do leite foram realizadas pelo Laboratório UNIANÁLISES da Universidade do Vale 
do Taquari - UNIVATES, segundo as metodologias definidas pelas ISO 21187 | I DF196:2004, ISO 13366-2 | IDF148-2:2006 e ISO 21187|IDF196:2004, respectivamente.

Para avaliar a concentração de ozônio presente na água utilizou-se um medidor de ozônio da marca Analytical Technology INC (ATI) e modelo Q46H/64. Foi aplicado o sistema de ozonização em uma amostra de $500 \mathrm{~mL}$ de água, que circulou pelo sistema em um ciclo fechado. Através de um eletrodo fixado no sistema mediu-se a concentração de ozônio presente na água, garantindo que a mesma esteja ozonizada. A análise foi realizada em triplicata.

Após a determinação dos parâmetros microbiológicos realizou-se uma comparação em relação aos dois sistemas de desinfecção e suas eficiências. Diante dos resultados, foi avaliada a viabilidade econômica e ambiental da aplicação do processo de desinfecção utilizando a água ozonizada em substituição ao método convencional.

Para a viabilidade econômica considerou-se os gastos de energia para o aquecimento da água de desinfecção e sua quantidade utilizada nos enxágues necessários após a desinfecção convencional. Além disso, foram considerados os custos dos produtos químicos utilizados, bem como do equipamento para a ozonização. Para a análise da viabilidade ambiental observou-se a quantidade de água utilizada nos processos de desinfecção e, ainda, a geração de efluentes contaminantes gerados nos processos.

\section{RESULTADOS E DISCUSSÃO}

A análise da água ozonizada utilizada neste trabalho apresentou uma concentração de ozônio residual de $0,049 \pm 0,001 \mathrm{ppm}$, a $23{ }^{\circ} \mathrm{C}$. Como descrito por Silva et al. (2011), a temperatura tem uma relação importante com a solubilidade do gás em água, uma vez que com temperaturas elevadas o ozônio tem a sua capacidade de solubilização reduzida. Dessa forma, torna-se importante manter a água do sistema em temperatura ambiente. Além disso, o parâmetro encontrado condiz com a legislação brasileira sobre a exposição ao gás. A Instrução Normativa $\mathrm{N}^{\circ} 15$, que cita os limites de tolerância de agentes químicos e foi aprovada pela Portaria $N^{\circ} 3.214 / 78$ e limita em 0,08 ppm de ozônio no ambiente (BRASIL, 2011).

A Tabela 1 apresenta os resultados de CBT (x1000 UFC/mL) e CCS (x1000 cél. $/ \mathrm{mL}$ ) para a primeira etapa do trabalho, onde se utilizou somente o sistema convencional de desinfecção no processo de ordenha canalizada. 
Tabela 1 - Resultados obtidos utilizando o método convencional no processo de desinfecção do sistema de ordenha canalizada.

\begin{tabular}{c|c|c|c}
\hline Semana & Turno & CCS $(\mathbf{x 1 0 0 0}$ cél./mL) & CBT (x1000 UFC/mL) \\
\hline Primeira & A & 302 & 110 \\
\hline Segunda & A & 385 & 128 \\
\hline Terceira & A & 309 & 173 \\
\hline Quarta & A & 317 & 105 \\
\hline
\end{tabular}

Fonte: Dos autores (2018).

Os parâmetros de CBT (x1000 UFC/mL)eCCS (x1000 cél./mL) foram avaliados para o processo utilizando o sistema com água ozonizada em substituição a uma higienização química. Os resultados obtidos estão apresentados na Tabela 2.

Tabela 2 - Resultados obtidos utilizando água ozonizada no processo de desinfecção do sistema de ordenha canalizada.

\begin{tabular}{c|c|c|c}
\hline Semana & Turno & CCS (x1000 cél./mL) & CBT (x1000 UFC/mL) \\
\hline \multirow{2}{*}{ Primeira } & $\mathrm{A}$ & 632 & 38 \\
\cline { 2 - 4 } & $\mathrm{B}$ & 755 & 26 \\
\hline \multirow{3}{*}{ Segunda } & $\mathrm{A}$ & 493 & 54 \\
\cline { 2 - 4 } & $\mathrm{B}$ & 457 & 41 \\
\hline \multirow{2}{*}{ Terceira } & $\mathrm{A}$ & 482 & 56 \\
\cline { 2 - 4 } & $\mathrm{B}$ & 454 & 51 \\
\hline \multirow{2}{*}{ Quarta } & $\mathrm{A}$ & 577 & 91 \\
\cline { 2 - 4 } & $\mathrm{B}$ & 605 & 107 \\
\hline
\end{tabular}

Fonte: Dos autores (2018).

Avaliando os resultados obtidos durante o estudo, é possível observar um aumento nos níveis de CCS encontrados na segunda etapa do trabalho, na qual utilizou-se água ozonizada. Os resultados ultrapassaram os limites permitidos por legislação para a comercialização de leite cru refrigerado que é de 400 (x1000 cél./mL). Os valores de células somáticas estão relacionados estritamente com a saúde do animal e não ao processo de desinfecção do sistema. O aumento desse parâmetro pode estar ligado a mastite, caracterizada por ser uma infecção bacteriana das glândulas mamárias provocada por agentes físicos, químicos ou biológicos, ou a alguma infecção generalizada presente no animal. Em animais saudáveis os valores de CCS costumam ser menores que 200 (x1000 cél./mL)(GRANATO; NUNES, 2016). 
Diante dos valores obtidos para as duas etapas do trabalho, é possível perceber que houve uma redução na CBT do leite avaliado quando a desinfecção do sistema foi realizada com água ozonizada. Considerando que a legislação estabelece um limite máximo de 100 (x1000 UFC/mL), observa-se que durante a aplicação do sistema convencional este parâmetro ficou acima do permitido, enquanto o sistema utilizando água ozonizada atendeu padrões exigidos pela legislação.

Dentre os resultados apresentados na Tabela 2, com a utilização de água ozonizada, encontrou-se um parâmetro acima dos valores permitidos pela legislação. Na quarta semana, no turno B, a amostra apresentou um nível de CBT de 107 (x1000 UFC/mL). Esse valor pode estar relacionado a alguma falha no processo de desinfecção, no qual os microrganismos se proliferaram e resultaram em uma alteração na contagem de bactérias. Conforme Carvalho et al. (2013), altos teores de CBT podem ser influenciados pela má higienização dos equipamentos, pelo resfriamento não eficiente do leite ou até mesmo por falhas na refrigeração do produto.

Cavalcante et al. (2013), avaliaram a potencialidade da desinfecção de tetos bovinos utilizando água ozonizada na concentração de 2 ppm em substituição a clorexidina, antisséptico padrão da higienização de tetos de vacas na pré ordenha. Os autores observaram que a substituição do método convencional por água ozonizada foi eficiente na sanitização e pode ser aplicado sem prejuízo para a qualidade microbiológica e físico-química do leite in natura.

Em trabalho realizado por Güzel-Seydim; Bever; Greene, (2004), foi comparada a utilização de água ozonizada a 0,4 ppm contra o crescimento de Bacillusstearothermophilus, Escherichia coli e Staphylococcus aureus, na presença de amido, proteína e gordura. A água ozonizada apresentou-se eficiente no combate a proliferação de Escherichia coli e Staphylococcus aureus, bactérias que também estão presentes no leite, em amostras com proteína e gordura.

Além dos teores de CCS e CBT, também é importante avaliar a composição do leite que será comercializado. Diante disso, a Tabela 3 apresenta os valores de gordura, proteína, lactose, sólidos totais (ST) e extrato seco desengordurado (ESD) avaliados para o sistema convencional e com água ozonizada na desinfecção do sistema de ordenha canalizada. 
Tabela 3 - Resultados obtidos para a composição do leite utilizando o sistema convencional e o sistema com água ozonizada no processo de desinfecção do sistema de ordenha canalizada.

\begin{tabular}{|c|c|c|c|c|c|c|}
\hline \multicolumn{7}{|c|}{ Sistema convencional } \\
\hline Semana & Turno & $\begin{array}{l}\text { Gordura } \\
\text { (g/ 100g) }\end{array}$ & $\begin{array}{l}\text { Proteína } \\
\text { (g/ 100g) }\end{array}$ & $\begin{array}{l}\text { Lactose } \\
\text { (g/ 100g) }\end{array}$ & $\begin{array}{c}\text { ST } \\
(\mathrm{g} / 100 \mathrm{~g})\end{array}$ & $\begin{array}{c}\text { ESD } \\
(\mathrm{g} / \mathrm{100g})\end{array}$ \\
\hline Primeira & A & 4,29 & 3,65 & 4,45 & 13,51 & 9,22 \\
\hline Segunda & A & 4,31 & 3,64 & 4,45 & 13,52 & 9,21 \\
\hline Terceira & A & 4,59 & 3,53 & 4,48 & 13,65 & 9,06 \\
\hline Quarta & $\mathrm{A}$ & 4,51 & 3,56 & 4,49 & 13,61 & 9,1 \\
\hline \multicolumn{7}{|c|}{ Sistema com ozonização } \\
\hline Semana & Turno & $\begin{array}{l}\text { Gordura } \\
\text { (g/ 100g) }\end{array}$ & $\begin{array}{l}\text { Proteína } \\
\text { (g/ 100g) }\end{array}$ & $\begin{array}{l}\text { Lactose } \\
(\mathrm{g} / 100 \mathrm{~g})\end{array}$ & $\begin{array}{c}\text { ST } \\
(g / 100 g)\end{array}$ & $\begin{array}{c}\text { ESD } \\
(\mathrm{g} / \mathrm{100g})\end{array}$ \\
\hline \multirow{2}{*}{ Primeira } & $\mathrm{A}$ & 4,49 & 3,68 & 4,6 & 13,86 & 9,37 \\
\hline & $\mathrm{B}$ & 4,62 & 3,68 & 4,56 & 13,98 & 9,36 \\
\hline \multirow{2}{*}{ Segunda } & A & 4,51 & 3,66 & 4,57 & 13,84 & 9,33 \\
\hline & B & 4,52 & 3,63 & 4,54 & 13,79 & 9,27 \\
\hline \multirow{2}{*}{ Terceira } & $\mathrm{A}$ & 4,34 & 3,65 & 4,42 & 13,43 & 9,09 \\
\hline & B & 4,37 & 3,67 & 4,43 & 13,5 & 9,13 \\
\hline \multirow{2}{*}{ Quarta } & $\mathrm{A}$ & 4,28 & 3,67 & 4,38 & 13,41 & 9,13 \\
\hline & B & 4,25 & 3,67 & 4,37 & 13,38 & 9,13 \\
\hline
\end{tabular}

Fonte: Dos autores (2018).

Os resultados apresentados demonstram que não houve alteração na composição do leite com a substituição do sistema convencional de desinfecção do sistema de ordenha mecanizada pela utilização da água ozonizada. Todos os valores obtidos, para os dois sistemas, encontram-se dentro dos parâmetros mínimos exigidos pela Instrução Normativa $\mathrm{N}^{\circ} 51$ para gordura (mínimo de 3,0 g/ 100 g), proteína (mínimo de 2,9 g/ 100 g), lactose (mínimo de 4,3 g/ 100 g), ST (mínimo de 8,4 g/ 100 g) e ESD (mínimo de 11,4 g/ 100 g) (BRASIL, 2002).

Além dos resultados apresentados nas avaliações microbiológicas, permitindo que o leite possa ser comercializado após a desinfecção utilizando água ozonizada, é preciso que o sistema seja econômico e ambientalmente viável. Para isso, foi realizado um estudo para comparação quanto as questões econômicas e ambientais dos dois processos de desinfecção. A Figura 2 apresenta os principais custos envolvidos no processo de desinfeç̧ão convencional, comparado com a utilização da água ozonizada, considerando um período de avaliação de 30 dias. 
Figura 2 - Avaliação da viabilidade econômica para os sistemas de desinfecção convencional e com água ozonizada para o período de 30 dias.

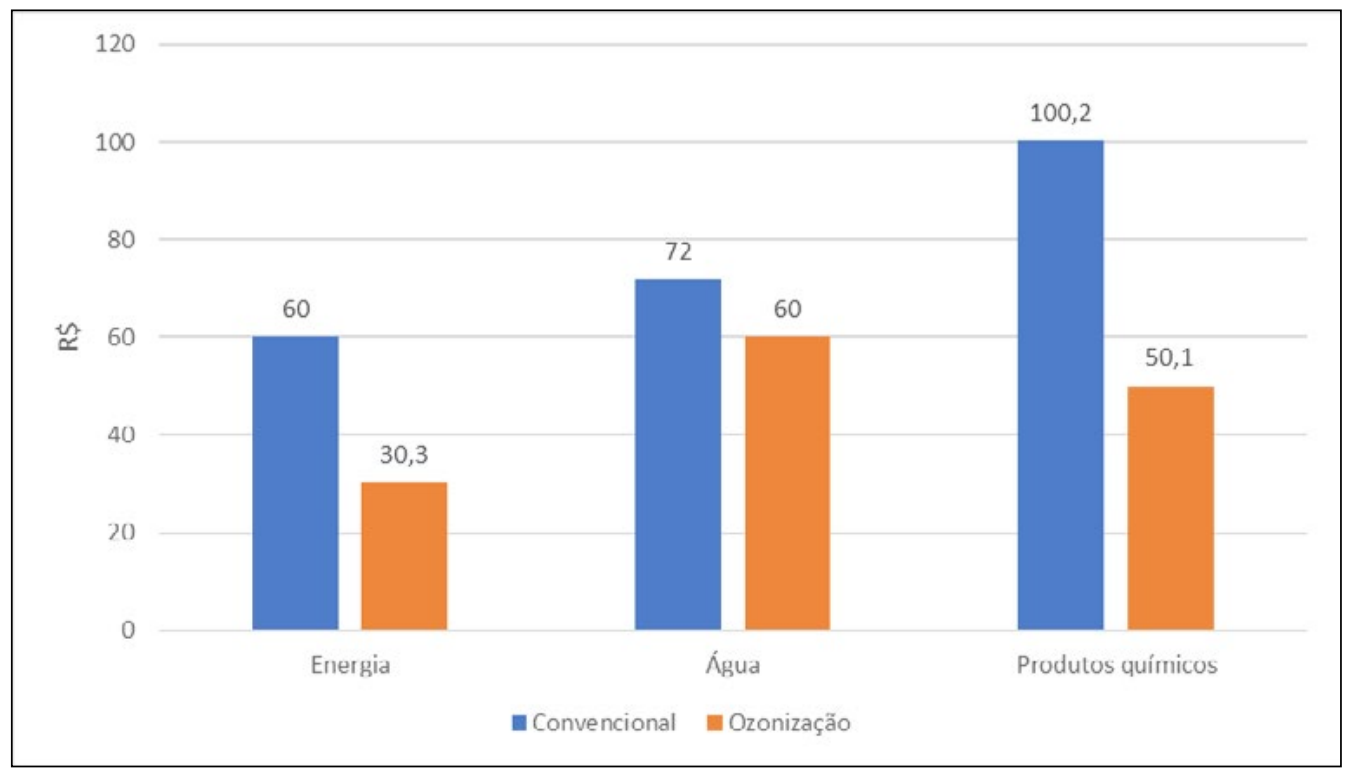

Fonte: Dos autores (2018).

Considerando os valores observados na Figura 2, pode-se identificar um decréscimo no custo total do processo de desinfecção ao se utilizar água ozonizada. No processo de desinfecção convencional são gastos com energia, água e produtos químicos, $\mathrm{R} \$ 232,20$ por mês. Já no processo de ozonização o custo total mensal é de $\mathrm{R} \$ 140,40$. A economia mensal ficou em $\mathrm{R} \$ 91,80$. Como houve uma redução no número de enxágues e na quantidade de produtos químicos utilizados, isso impactou também nos custos do processo. $\mathrm{O}$ custo mensal de água teve uma redução de $R \$ 12,00$ enquanto que nos gastos com produtos químicos houve uma redução de $R \$ 50,10$. A energia elétrica necessária para aquecer água utilizada na desinfecção química gerou uma despesa de $\mathrm{R} \$ 60,00$ por mês, considerando que foram utilizados $2500 \mathrm{~W}$ por 2 h, que custavam $R \$ 0,40$ a cada 1000 watts. Já a geração de ozônio, durante 15 minutos de aplicação, consome $100 \mathrm{~W}$, o que resulta em uma despesa mensal de $R \$ 0,30$. Adicionando a esse valor um ciclo de desinfecção convencional, que utiliza $2500 \mathrm{~W}$ por $2 \mathrm{~h}$, o custo total mensal do processo de desinfecção com água ozonizada é de $\mathrm{R} \$ 30,30$.

Além disso, é preciso destacar que ao atingir os parâmetros de CBT e CCS exigidos pela legislação o produtor é bonificado com $\mathrm{R} \$ 0,04$ por litro de leite comercializado. Considerando que a propriedade onde o estudo foi realizado possui uma produção mensal de $10.500 \mathrm{~L}$, há um aumento de $\mathrm{R} \$$ 420,00 na renda do agricultor por bons resultados. 
Considerando o volume de água e produtos químicos utilizados durante um mês, foi possível comparar a viabilidade ambiental dos processos estudados. No processo de desinfecção convencional eram realizados quatro enxágues e duas desinfecções químicas, gerando um consumo de $7200 \mathrm{~L}$ de água e de $12 \mathrm{~L}$ de produtos químicos. No entanto, com a desinfecção utilizando água ozonizada foi possível reduzir para somente dois enxágues, uma desinfecção química e duas desinfecções com água ozonizada, sendo que os outros enxágues reutilizam a água da ozonização. Como são utilizados $40 \mathrm{~L}$ de água em cada um desses processos, foi possível reduzir em $1200 \mathrm{~L}$ o consumo de água do processo, que ficou em 6000 L. É importante salientar que após o processo de ozonização não existe a necessidade de enxágue, uma vez que não existem produtos químicos que possam ter ficado retidos nos equipamentos e tubulações. Quanto ao volume de efluentes químicos gerados, também houve uma redução. Como esses serão utilizados somente uma vez ao dia, esse volume apresentou uma redução de $6 \mathrm{~L}$ de produto químico por mês.

Portanto, com a utilização do sistema com água ozonizada foi possível reduzir os custos do processo, bem como a geração de efluentes contaminantes e a utilização de água. É importante destacar que mesmo sendo eficiente contra diversos organismos, os produtos químicos convencionalmente utilizados na desinfecção de sistemas são prejudiciais ao meio ambiente. Compostos clorados, comumente utilizados nesse processo, podem afetar a vida aquática de rios, bem como diminuir a qualidade da água potável. Diante disso, são estudadas alternativas que possam diminuir a geração de resíduos e uma delas é o ozônio, é uma alternativa viável nos aspectos ambientais e econômicos (COELHO et al., 2015; KIM et al., 1999).

\section{CONCLUSÃO}

Diante dos resultados apresentados, pode-se concluir que a utilização da água ozonizada a uma concentração de 0,049 ppm por 15 minutos, se mostrou eficiente na remoção de bactérias presentes no processo de ordenha canalizada. Nas condições apresentadas, esse modelo alternativo de desinfecção pode ser utilizado e o leite é considerado apto para consumo atendendo os parâmetros da legislação com relação a CCS, CBT e composição.

Além disso, a ozonização torna-se ambientalmente viável uma vez que um processo químico com geração de efluentes contaminantes utilizado convencionalmente, é substituído por um sistema que utiliza um gás altamente reativo, de fácil degradação e que não gera poluentes. Outro fator importante da ozonização é o fato de ser utilizada água em temperatura ambiente, ao contrário do sistema convencional que utiliza água a $75^{\circ} \mathrm{C}$ no processo de desinfecção. Consequentemente há uma diminuição no gasto de energia do processo ao aplicar o sistema alternativo. 


\section{AGRADECIMENTOS}

Agradecemos à Universidade do Vale do Taquari - Univates, ao Unianálises, ao Tecnovates e à ALVAP Engenharia Ltda. pelo apoio prestado durantes a realização dessa pesquisa.

\section{REFERÊNCIAS}

BEIRÃO-DA-COSTA, S.; GUEDES, M. C.; PINTO, M. M.; EMPIS, J.; MARTINS, M. M. Alternative sanitizing methods to ensure safety and quality of fresh-cut kiwifruit. Journal of Food Processing and Preservation, New Jersey, v. 38, p. 1-10, 2014.

BRASIL. Ministério da Agricultura, Pecuária e Abastecimento (MAPA). Instrução Normativa $n^{\circ} 15$ de 08 de junho de 1978. Norma Regulamentadora para Atividades e Operações Insalubres. Ministério do Trabalho e Emprego, 1978. Disponível em: <http://www.camara.gov.br/sileg/integras/333673.pdf>. Acesso em: 1 nov. 2017.

BRASIL. Ministério da Agricultura, Pecuária e Abastecimento (MAPA). Instrução Normativa $\mathbf{n}^{0} 51$ de 18 de setembro de 2002.Regulamentos Técnicos de Produção, Identidade e Qualidade do Leite, 2002. Disponível em: <http:/ /adcon.rn.gov.br/ ACERVO/EMATER/DOC/DOC000000000001051.PDF>. Acesso em: 17maio 2018.

BRASIL. Ministério da Agricultura, Pecuária e Abastecimento (MAPA). Instrução Normativa ${ }^{\circ} 62$ de 29 de dezembro de 2011. Diário Oficial da República Federativa do Brasil, Brasília, 30 dez. 2011. Seção 1, p.1-24. Disponível em: <http://www.apcbrh. com.br/files/IN62.pdf>. Acesso em: 20 out. 2017.

CARVALHO, T. S.; SILVA, M. A. P.; BRASIL, R. B.; CABRAL, J. F.; GARCIA, J. C.; OLIVEIRA, A. N. Qualidade do leite cru refrigerado obtido através de ordenha manual e mecânica. Revista do Instituto de Laticínios Cândido Tostes, Juiz de Fora, v.68, n.390, p.05-11, 2013.

CAVALCANTE, D. A.; JUNIOR, B. L.; TRIBST, A.A.L.; CRISTIANINI, M. Vida de prateleira de alface americana tratada com água ozonizada. Ciência Rural, Santa Maria, v.45, n.11, p.2089-2096, 2015.

CAVALCANTE, D. A.; JUNIOR, B. L.; TRIBST, A. A. L.; CRISTIANINI, M.; COELHO, V. P., Uso da água ozonizada na sanitização de tetos de bovinos e sua influência na qualidade do leite. Revista do Instituto de Laticínio Cândido Tostes, Juiz de Fora, v. 68, n. 392, p. 33-39, 2013.

COELHO, C. C.; SILVA, O. F.; CAMPOS, R. S.; BEZERRA, V. S.; CABRAL, L. C. Ozonização como tecnologia pós-colheita na conservação de frutas e hortaliças: uma revisão. Revista Brasileira de Engenharia Agrícola e Ambiental, Campina Grande, v.19, n.4, p.369-375, 2015.

CÔNSOLI, M. A.; NEVES, M. (Coord.). Estratégias para o leite no Brasil. São Paulo: Atlas, 1.ed., 2006. 
O'DONNELL, B. K; TIWARI, P. J.; CULLENRIP, G. RICE. Ozone in food processing. Oxford: Blackwell Publishing Ltd. Published, 1. ed., 2012.

FAO - FOOD AND AGRICULTURE ORGANIZATION OF THE UNITED NATIONS. Guia de Boas Práticas na Pecuária Leiteira, 2013. Disponível em: <http:/ /www.fao. org/docrep/017/ba0027pt/ba0027pt.pdf>. Acesso em: 20 out. 2017.

GRANATO, D., NUNES, D. S. Análises químicas, propriedades funcionais e controle da qualidade de alimentos e bebidas: uma abordagem teórico-prática. Rio de Janeiro: Elsevier, 1.ed., 2016.

GREENE, A. K.; FEW, B. K.; SERAFINI, J. C. A Comparison of Ozonation and Chlorination for the Disinfection of Stainless Steel Surfaces. Journal of Diary Science, v. 76, p. 3617-3620, 1993.

GUZEL-SEYDIM, Z.; BEVER, P. I.; GREENE, A. K., Efficacy of ozone to reduce bacterial populations in the presence of food componentes. Food Microbiology, Amsterdam, n.21, p.475-479, 2004.

GUZEL-SEYDIM, Z. B.; GREENE, A. K.; SEYDIM, A. C. Use of ozone in the food industry. LWT - Food Science and Technology, Philadelphia, v. 37, n. 4, p. 453-60, 2004.

IBGE - INSTITUTO BRASILEIRO DE GEOGRAFIA E ESTATÍSTICA. Censo Agropecuário: Estatística da Produção Pecuária, 2017. Disponível em: <https:/ / biblioteca.ibge.gov.br/visualizacao/periodicos/2380/epp_2017_dez.pdf>. Acessoem: 09 mar. 2017.

KIM, J. G.; YOUSEF, A. E.; DAVE, S. Application of ozone for enhancing the microbiological safety and quality of foods: a review. Journal of Food Protection. v. 62, n. 9, p. 1071-87, 1999.

LANITA, C. S.; SILVA, S. B. Uso de ozônio em câmara industrial para controle de bolores e leveduras durante a maturação de queijo tipo parmesão. Brazilian Journal of Food Technology, Campinas, v. 11, n. 3, p. 182-189, 2008.

MENDONÇA, L. C.; GUIMARÃES, A.; BRITO, M. A. V., Higienização do equipamento de ordenha mecânica. Embrapa Gado de Leite, 2012, p.1-2. (Comunicado Técnico; 64). Disponível em: <https://www. infoteca.cnptia.embrapa.br/infoteca/bitstream/doc/930341/1/ COT64HigienizacaodoequipamentodeordenhamecanicaLeticiaMendoncan64.pdf $>$. Acesso em: 18 set. 2017.

ORDÓÑES, J. A. Tecnologia de Alimentos: Alimentos de origem animal.Porto Alegre: Artmed. 2.ed., 2005.

RESTAINO, L.; FRAMPTON, E. W.; HEMPHILL, J. B.; PALNIKAR, P. Efficacy of Ozonated Water agains Various Food-Related Microorganisms. Appliedand Environmental Microbiology, Washington DC, v.61, n.9, p. 3471-3475, 1995. 
RIBEIRO, H. P.; FARONI, L. R.; FINGER, F. L.; CECON, P. R.; HELENO, F. F.; SANTOS, R. R. Ozônio como agente fitossanitário na conservação pós-colheita da bata-baroa. Brazilian Journal of Food Technology, Campinas, v. 20, p. e2016137, 2017.

ROBERTO, M. A.; ALENCAR, E. R.; FERREIRA, W. F. S.; MENDONÇA, M. A.; ALVES, H. Saturação do ozônio em coluna contendo grãos de amendoim e efeito na qualidade. Brazilian Journal of Food Technology, Campinas v. 19, p. e2015051, 2016.

ROSA, J.; DOMINGUES, L. P.; LIMA, H., CERESER, N. D. Pontos Críticos de Contaminação na Produção Leiteira. Expressa Extensão, Pelotas, v.22, n.1, p.90-103, 2017.

SHMIDELL, W. Biotecnologia Industrial: engenharia bioquímica. São Paulo: Bluncher. 2.ed. 2001.

SILVA, S. B.; LUVIELMO, M. M.; GEYER, M. C.; PRÁ, I. Potencialidades do uso do ozônio no processamento de alimentos. Semina: Ciências Agrárias, Londrina, v. 32, n. 2, p. 659-682, 2011. 